\title{
Contemporary Role of Robotics in Bariatric Surgery: Experience of CUF Infante Santo Hospital
}

Papel Atual da Robótica na Cirurgia Bariátrica: A Experiência do Hospital CUF Infante Santo

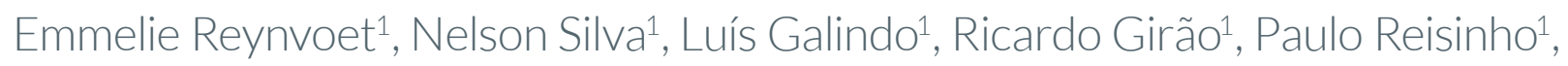
Carlos Vaz $^{1}$

\section{ABSTRACT}

INTRODUCTION: The use of robotics in bariatric surgery is increasing worldwide, with the main objective of reducing complications and optimising surgical outcome. This study presents a single centre 1.5-year experience and clinical outcome with robotic gastric bypass.

METHODS: A retrospective review was performed of 42 consecutive patients who underwent a robotic gastric bypass. Patient files were analysed to obtain patient characteristics, weight loss results and per-and postoperative morbidity.

RESULTS: In 32/42 patients, a primary gastric bypass was performed, the remaining 10 procedures were revision cases. Mean start weight was $111.1(+/-20.5) \mathrm{kg}$, mean start BMI was $39.7(+/-5.6) \mathrm{kg} / \mathrm{m}^{2}$. Almost half of the patients presented with pre-existing comorbidities.

After a mean follow-up of 9.1 (+/-5.2) months, mean body mass index was $30.16(+/-5.3) \mathrm{kg} / \mathrm{m}^{2}$ with a percentage excess weight loss of 66.16 (+/-43.6)\%. There were no conversions, no leaks and no mortality. Two patients presented with minor complications; one infected hematoma and one anastomotic ulcer. Mean length of stay in the hospital was 2.8 (2-5) days. All but one patients were satisfied with the weight loss result.

CONCLUSION: The robotic gastric bypass is a safe and reproducible approach to treat morbid obesity. A secure handsewn gastrojejunal anastomosis, quick recovery and better ergonomics are the main advantages of this technique.

KEYWORDS: Body Mass Index; Gastric Bypass; Obesity/surgery; Robotic Surgical Procedures 


\section{RESUMO}

INTRODUÇÃO: A utilização da robótica na cirurgia bariátrica tem vindo a aumentar a nível mundial, com o objetivo principal de reduzir complicações e otimizar o resultado cirúrgico final. Este estudo apresenta a experiência e resultados clínicos de um ano e meio de bypass gástrico robótico de um único hospital.

MÉTODOS: Foi realizada uma revisão retrospetiva de 42 doentes consecutivos submetidos a bypass gástrico robótico. Os ficheiros dos doentes foram analisados no sentido de obter as características dos doentes, resultados da perda de peso e morbilidade peri e pós-operatória.

RESULTADOS: Em 32/42 dos doentes foi realizado um bypass gástrico primário e os restantes 10 procedimentos foram casos de revisão. O peso inicial médio era 111,1 (+/- 20,5) kg e o índice de massa corporal (IMC) inicial médio era 39,7 (+/- 5,6) $\mathrm{kg} / \mathrm{m}^{2}$. Quase metade dos doentes tinha comorbilidades pré-existentes. Após um seguimento médio de 9,1 (+/- 5,2) meses, o IMC médio era 30,16 (+/- 5,3) kg/m² com uma percentagem de perda de peso excessivo de 66,16 (+/- 43,6)\%. Não houve necessidade de conversão, deiscências de anastomoses, nem mortalidade. Dois doentes apresentaram complicações menores: um hematoma infetado (morbilidade Clavien-Dindo IIIb) e uma úlcera de anastomose. A duração média de internamento no hospital foi de 2,8 (2-5) dias. Todos os doentes, à exceção de um, ficaram satisfeitos com o resultado da perda de peso.

CONCLUSÃO: O bypass gástrico robótico é uma abordagem segura e reprodutível para tratar a obesidade mórbida. Uma anastomose gastrojejunal segura e manual, recuperação rápida e uma ergonomia melhor são as principais vantagens desta técnica nesta operação.

PALAVRAS-CHAVE: Bypass Gástrico; Índice Massa Corporal; Obesidade/cirurgia; Procedimentos Cirúrgicos Robóticos

\section{INTRODUCTION}

Obesity and overweight is a growing problem. Global incidence of obesity is increasing fast and becoming an important public health issue. The World Health Organization (WHO) stated that, in 2016,39\% of adults were overweight (body mass index - BMI $\geq 25 \mathrm{~kg} / \mathrm{m}^{2}$ ) and $13 \%$ were obese $\left(\mathrm{BMI} \geq 30 \mathrm{~kg} / \mathrm{m}^{2}\right)$. Presently, worldwide there are more people obese than underweight. ${ }^{1}$

With obesity comes a higher risk of obesity-related comorbidities such as: cardiovascular diseases, diabetes, certain cancer types, sleep apnoea and musculoskeletal disorders. The risk for these associated diseases increases with increasing BMI.

As a treatment of obesity, bariatric surgery has shown to be superior to any other treatment option, not only for weight loss, but also for obesity-related comorbidities.

In a large prospective trial, the Stampede Trial, the beneficial effects of bariatric surgery were proven. With surgery, glycaemic control was sustainable on the longterm, 5 years, and led to a significant reduction of the use of diabetes and cardiovascular medication. ${ }^{2}$

It is true that the first bariatric procedures, described in the early 70's, by Scopinaro, Mason, Pories, Buchwald, etc. were associated with a high morbidity rate, although these authors were pioneers in weight loss surgery and played an important role in the development of different weight loss procedures.

The first procedures were jejunoileal bypass, Roux-en-Y gastric bypass (RNY), vertical banded gastroplasty, biliopancreatic diversion, duodenal switch, adjustable gastric banding and sleeve gastrectomy. Soon, the Roux-en-Y gastric bypass turned out to be the preferred operation regarding weight loss, metabolic benefits, and low complication rate. With the publication of the first laparoscopic RNY by Wittgrove et al in 1994, it gained general acceptance as the principal bariatric procedure. ${ }^{3}$

In bariatric surgery, complications are, relatively spoken, more unexpected than in other disciplines because we are dealing with young patients, who are working and who consider themselves as being "healthy". In attempt to avoid those complications, surgeons are looking to evolve new techniques with better view, more control and finer tissue dissection. The robot could meet in achieving this goal. When using the robot, the surgeon is controlling the operation from a console located in the operation room. The robot is docked and thereafter the arms and instruments are installed under direct vision. With this setup, an optimal 3D vision is created with a magnified view inside the abdomen. The instruments are handled in a smaller working space and with more precise movements. ${ }^{4}$

In this paper, we present you the results of the first series of robotic gastric bypasses in CUF Infante Santo Hospital, Lisbon, Portugal.

\section{MATERIAL AND METHODS}

Between the $1^{\text {st }}$ of May 2016 and $31^{\text {st }}$ of December 2017, 42 consecutive patients underwent a robotic gastric bypass. All procedures were performed by the same surgeon and are totally robotic gastric bypass procedures, operated according to a standardized technique 
as is described below. A retrospective review of the data, collected from the patient files, was performed.

In our centre, all patients are well informed before the surgery. A personal contact with the surgeon is scheduled twice preoperative, as is a consultation with a specialized nutritionist, psychologist, and the anaesthetist. All patients need to sign the informed consent form before entering the operation theatre.

In Portugal, there is no reimbursement provided for any type of bariatric surgery. The indication depends on the motivation of the surgeon. In our centre, patients are planned for an operation from BMI $35 \mathrm{~kg} / \mathrm{cm}^{2}$ onwards. Patients with comorbidities such as diabetes or severe hypertension can be operated at a lower BMI (> $\left.30 \mathrm{~kg} / \mathrm{cm}^{2}\right)$. Indications for patients who had previous surgery (e.g. laparoscopic gastric banding, sleeve gastrectomy, or Mason operation) are looked case by case.

Patient characteristics and comorbidities are recorded and analysed by file review. The start weight is set as the weight on the day of the surgery. Comorbidities are looked up by reviewing the patient medication list. The duration of surgery is calculated as the time between incision and skin closure as is written down in the anaesthesia file.

\section{Preoperatively}

Patients are strongly advised to lose weight preoperatively. Five days before surgery patients receive low-molecular-weight heparin which is continued, except on the day of the surgery itself, for 10 extra days.

\section{Operative Technique}

All procedures are performed according to a standardized technique. No technical adaptations were done in this series. The Da Vinci Xi device (Intuitive Surgical ${ }^{\circledR}$, Sunnyvale, CA, USA) was used in all cases. The entire team, e.g. the nursing staff, anaesthesia department as well as the technical support team is familiar with the procedure. Briefly, the robotic RNY is constructed with a manual end to side gastrojejunal anastomosis and a side to side linear stapled enteroenterostomy. For the revisional procedures some technical adaptations are done which are not described in this paper further in detail.

Prophylactic antibiotics are distributed 30 minutes before surgery. Patients are positioned in a flat position with the arms stuck to the body. Three robotic ports are used, a camera robotic port and one extra port for the assistant. The robotic ports are placed in one line at the level of the umbilicus. The assistant port is placed slightly more up to the right upper quadrant. A fix liver retractor is introduced as well, which in total makes 6 incisions (Fig. 1). Before docking, the length of the limbs is defined. The ligament of Treitz is looked up and an orienting suture is placed at a length of $150 \mathrm{~cm}$ for the biliary limb.

The robot is docked from the left side of the patient.
TABLE 1. Patient Characteristics.

\begin{tabular}{|l|l|}
\hline Total & 42 patients \\
\hline Male & 11 \\
\hline Female & 31 \\
\hline Age & $50(+/-11.3)$ years \\
\hline Start weight & $111.1(+/-20.5) \mathrm{kg}$ \\
\hline Start BMI & $39.7(+/-5.6) \mathrm{kg} / \mathrm{m}^{2}$ \\
\hline Comorbidity & $12(28.5 \%)$ \\
\hline Diabetes & $3(7.1 \%)$ \\
\hline Diabetes treated with insulin & $19(45.2 \%)$ \\
\hline Hypertension & $5(11.9 \%)$ \\
GERD & $4(9.5 \%)$ \\
\hline Sleep apnoea & \\
\hline
\end{tabular}

TABLE2. Results.

\begin{tabular}{|l|l|}
\hline Length of follow-up & $9.1(+/-5.2)$ months \\
\hline Start BMI & $39.7(+/-5.6) \mathrm{kg} / \mathrm{m}^{2}$ \\
\hline Final BMI & $30.16(+/-5.3) \mathrm{kg} / \mathrm{m}^{2}$ \\
\hline BMI units lost & $9.71(+/-4.05)$ \\
\hline Absolute weight loss & $27.19(+/-11.7) \mathrm{kg}$ \\
\hline Percentage excess weight loss & $66.16(+/-43.6)$ \\
\hline
\end{tabular}

First, a gastric pouch is created with a powered stapling device (Fig. 2). Secondly, the manual gastrojejunal anastomosis is constructed (Fig. 3). The biliary limb is lifted up and positioned with the efferent part in the correct direction. A $30 \mathrm{~cm}$ Vicryl 3/0 stitch is used to make the first layer of the gastroenterostomy. An opening is made in the gastric pouch and in the jejunum and the inner layer of the anastomosis is made on the guidance of the gastric tube (34Fr) with 2 ready-mades knotted Vicryl $3 / 0$ sutures. For the anterior side of the second layer, the $30 \mathrm{~cm}$ suture is used again. Thirdly, the Roux-en-Y connection is performed. The alimentary limb is generally taken at $150 \mathrm{~cm}$. The jejunojejunostomy is done by a linear stapler and the defect is closed with a Vicryl 3/0 suture again. Finally, the two mesenteric gaps are closed with a non-resorbable Ethibond 3/0 running suture. At the end of the procedure a meticulous leak test is performed with introducing $60 \mathrm{~mL}$ of methylene blue by the gastric tube. No drains are left and the gastric tube is removed at the end of the procedure.

\section{Postoperatively}

Patients are admitted to the general surgical ward postoperatively. Clear liquids are allowed on the same day. After clinical evaluation, the oral intake can be increased as is prescribed by the protocol. Discharge is discussed with the patient and is generally advised at day 2 . When going home, patients are prescribed omeprazole (proton pomp inhibitor) and multivitamins. The habitual medication is reduced if possible. 


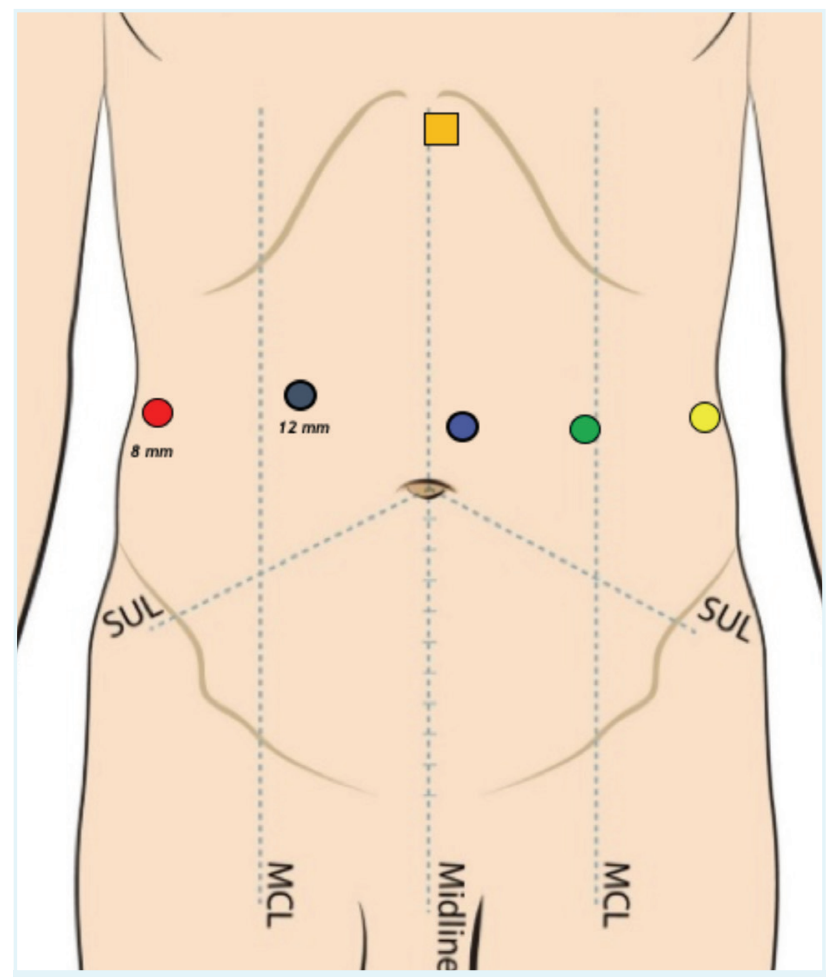

FIGURE 1. Trocar placement of regular gastric bypass. Five trocars: 1 camera trocar (blue) 3 robotic arms (dark blue, green, yellow) 1 assistant port (red) + one liver retractor (orange).

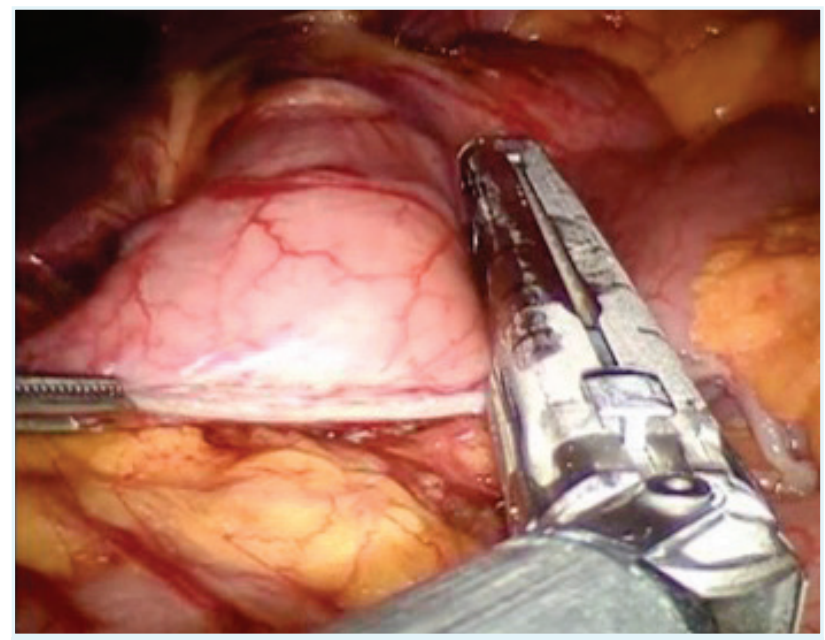

FIGURE 2. Creation of the pouch with a linear stapling device. Calibration of the pouch size is done with the guidance of the gastric tube.

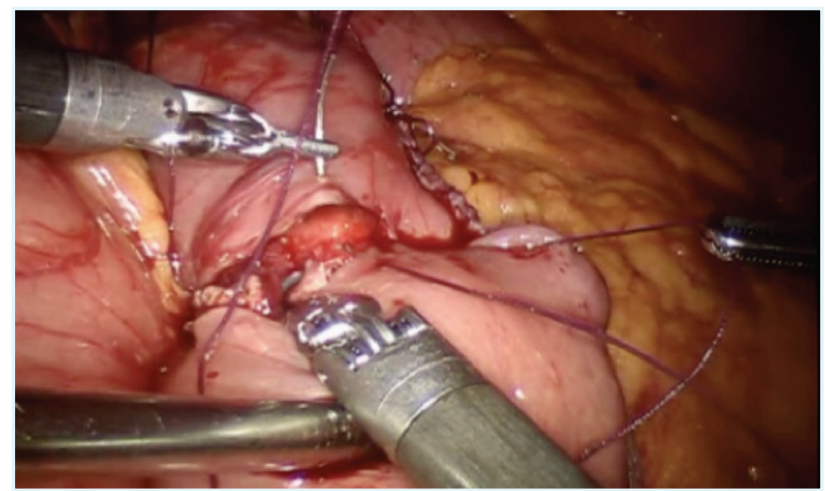

FIGURE 3. Gastrojejunal anastomosis. The anastomosis is hand sewn with a vircyl $3 / 0$ suture. The picture nicely shows the positioning of the three robotic arms (two for suturing, the third is used to align the gastric pouch).
Patients are followed-up at regular time points: each 3 months until one year, each 6 months during the second and third year and yearly thereafter if no further complaints persist. A blood test is requested on each of this follow-up times.

\section{Statistics}

All data are noted as mean (+/- standard deviation).

For the analysis, final BMI is calculated, as well as total BMI units lost and percentage excess weight loss (initial $\mathrm{BMI}$ - final BMI / initial BMI - 25).

\section{RESULTS}

A total of 42 patients were operated during the study period. Patient characteristics are described in Table 1. Mean age at the time of operation was 50 years (+/-11.3). Male/female ratio was 3/1. Mean start weight was 111.1 (+/- 20.5) kg and mean start BMI was $39.7(+/-5.6) \mathrm{kg} / \mathrm{m}^{2}$.

In 32 patients, a primary RNY gastric bypass was performed. Six patients had a previous laparoscopic adjustable gastric banding, of which in 3 patients the band was still in place. In two patients, the band was removed previously because of band migration, and in one patient the band was removed earlier because of band intolerance. The other revisional cases included: one Sleeve conversion to a gastric bypass, one Scopinaro conversion to a regular gastric bypass and one Nissen fundoplication conversion to a gastric bypass and one pouch resizing with distalisation.

All operations were performed with the robot, no conversions could be reported. Mean operation time was 178.05 (+/-63.85) minutes.

There was one intraoperative complication in a patient with a large hiatal hernia. Because of devascularisation of the gastric pouch, a partial gastrectomy was needed to be performed.

Mean length of stay in the hospital was 2.8 (2-5) days.

In the early postoperative period three adverse events can be described. One patient had an epileptic insult during admission which was treated conservatively and had no further consequences. One patient had to be readmitted at postoperative day 7 because of fever and abdominal pain. An explorative laparoscopy was performed which revealed an infected hematoma in the mesentery which was drained successfully. One patient had an episode of hematemesis at 7 weeks postoperative; a gastroscopy revealed an ulcer at the gastroenterostomy.

Follow-up is complete in 41/42 patients. Mean follow-up time was $9.1(+/-5.2)$ months. Weight loss results are shown in Table 2.

Two patients needed to be operated again in the longterm follow-up period. One patient was treated for an 
internal hernia 6 months postoperative. A second patient was admitted for an abdominal pain syndrome suggestive for internal hernia, although perioperative no abnormalities could be seen.

During follow-up following complaints were noted in three patients: one patient is suffering from excessive weight loss and insomnia, one patient with depression and one patient with a - so far untreated- incisional hernia at the trocar site. All other patients are very happy with the result. There were no mortalities in this series.

\section{DISCUSSION}

The first robotic bariatric procedure was described in 1997 by Himpens et al. ${ }^{5}$ Since then, the use of the robot stepwise entered the operation room.

In our centre, the new-generation da Vinci $X{ }^{\circledR}$ platform is used (Fig. 4). With this platform, the robotic arms are arranged in a way they can turn on its own, enabling performing procedures in different quadrants without the need to replace the system.

Besides the advantages, only little data is available in literature. Most series are small and have a low level of evidence and quality. In general, weight loss results are similar to the laparoscopic approach. The reported benefits are a lower complication rate and faster recovery period while the drawbacks are a longer operation time and a higher cost.

We present the results of 42 consecutive patients operated at CUF Infante Santo Hospital in Lisbon. In this series, no serious adverse events were seen. Regarding, weight loss, length of stay in the hospital and complication rate, our results are similar to earlier described series. ${ }^{6-10}$ The largest comparative study, comparing robotic and laparoscopic approach is published by Buchs et al. ${ }^{11}$ The authors compared 388 robotic gastric bypasses to 389 laparoscopic cases. They confirmed the longer operation time in the robotic group (245 minutes versus 215 in laparoscopic group). Besides, they describe a reduction in conversion rate $10.8 \%$ for the robotic group versus to $4.9 \%$ for laparoscopic group) and a lower complication rate with a significant reduction in anastomotic leaks (one in the robotic group versus 13 in the laparoscopic group). Our mean operation time was 178.05 (+/-63.85) minutes. The operation time was calculated as a mean, regarding the inclusion of two very long procedures (> 5 hours), and the small group size, this shows artificially long. Most of the primary robotic gastric bypass did not take longer than 150 minutes.

To our personal opinion, there are two main benefits of the robotic approach: first, the hand sewn gastrojejunal anastomosis and secondly, the quick patient recovery. In a conventional gastric bypass, the gastrojejunal anastomosis is made by a stapling device. The better view of the robot and the manipulation of the robotic wrists al-

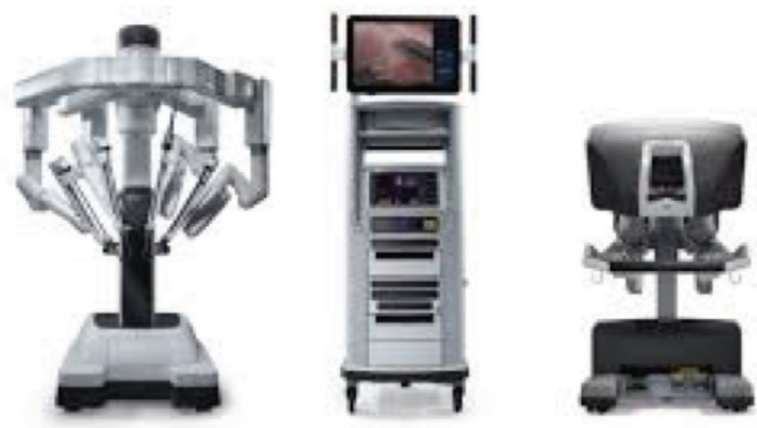

FIGURE 4. Da VinciXi ${ }^{\circledR}$ Robotic System.

low to perform a hand sewn manual anastomosis which is technically very difficult by laparoscopy. The dissection of the tissue is enhanced and a clear vision on both the gastric pouch and the jejunal loop is obtained. This way, the anastomosis can be nicely calibrated. Moreover, the risk of intraluminal bleedings is reduced by an inside vision of the lumen of the pouch.

We have the impression that patients are recovering faster after a robotic gastric bypass. Very soon after surgery they are able to mobilise, which reduces the risk of thromboembolic complications. The oral intake of liquids is motivated immediate after arousal, which avoids hypovolemia and enhances the recovery. Most of the patients are discharged after 2 days and return back to work after two weeks.

During surgery, the position of the patient is more stable than during laparoscopy. After docking, the trocars are not moved anymore. There is no traction on the trocars during the surgery and the position of the camera is stable and controlled by the surgeon. This way, there is less traction on the abdominal wall which can be the explanation of the reduction in postoperative pain and enhanced recovery.

The stable view and improved ergonomics are a major advantage for the surgeon itself. During surgery, the operator is comfortable and not dependent to the assistant for handling the camera.

The high cost remains the major concern for general implementation of the robotic system. However, the possible reduction of the complication rate may contribute to a general cost reduction in bariatric surgery. Hagen et al calculated that as robotic gastric bypass is associated with lower complications, lower anastomotic leaks and less reoperations, the general cost for society even is lower than a laparoscopic gastric bypass. ${ }^{12}$

Nowadays, the Da Vinci platform is still the only available one. The instruments are sold at a very high price. With development of new systems and upcoming concurrency, the prices will drop. 
The robot is also an effective tool for training, not only for future but also for experienced surgeons. They can train on virtual reality simulators which offer a high-quality vision very close to reality. This way a surgeon can prepare and train a procedure virtually before performing it on a real patient. In the future, it might be possible to merge the virtual model to the operative field. This way the live image and the previously prepared 3D model can be fused. This is what is called augmented reality. This can lead to new applications such as real-time virtual endoscopy, microscopic views and perioperative virtual histological examination. ${ }^{4}$

The number of institutions performing robotic surgery in Portugal is still very little; only 4 centres have a robotic system. It is true, the introduction of robotic surgery requires a high investment. Not only in equipment but also in training for the whole surgical team. After one and a half years we developed a standardized technique and every member of the team adapted very soon. The pre-existing large experience of the main surgeon in bariatric surgery as well as his experience in robotic surgery (> 300 cases) contributed to this smooth transition.

\section{CONCLUSION}

Robotic gastric bypass is a safe and reproducible procedure with good results regarding weight loss and reducing obesity-related comorbidities. The main advantage of the robotic technology is the enhanced vision and fine tissue manipulation. This results in better clinical outcome, e.g. less complications and faster recovery. In the future, with the decrease of costs and more experience, the use of robotics in bariatric surgery might be widespread appreciated.

CONFLICTS OF INTEREST: Emmelie Reynvoet, Nelson Silva, Luís Galindo, Ricardo Girão, Paulo Reisinho declare that they have no conflicts of interest. Carlos Vaz: Consultant for Intuitive Surgical Inc. and Consultant for Medtronic.

FINANCIAL SUPPORT: This work has not received any contribution, grant or scholarship.

CONFIDENTIALITY OF DATA: The authors declare that they have followed the protocols of their work center on the publication of data from patients.

PROTECTION OF HUMAN AND ANIMAL SUBJECTS: The authors declare that the procedures followed were in accordance with the regulations of the relevant clinical research ethics committee and with those of the Code of Ethics of the World Medical Association (Declaration of Helsinki).

CONFLITOS DE INTERESSE: Emmelie Reynvoet, Nelson Silva, Luís Galindo), Ricardo Girão, Paulo Reisinho declaram não ter qualquer conflito de interesse na realização do presente trabalho. Carlos Vaz: Consultor Intuitive Surgical Inc. e Consultor Medtronic.

FONTES DE FINANCIAMENTO: Não houve qualquer fonte de financiamento na realização do presente trabalho.

CONFIDENCIALIDADE DOS DADOS: Os autores declaram ter seguido os protocolos da sua instituição acerca da publicação dos dados de doentes.

PROTEÇÃO DE PESSOAS E ANIMAIS: Os autores declaram que os procedimentos seguidos na elaboração do presente trabalho estão em conformidade com as normas das comissões de investigação clínica e de ética, bem como da declaração de Helsínquia e da Associação Médica Mundial.

\section{REFERENCES}

1. World Health Organization. Obesity and Overweight. Geneve: WHO; 2018 [accessed Feb 2018]. Available from: http:// www.who.int/mediacentre/factsheets/fs311/en/.

2. Schauer P, Bhatt D, Kirwan J, Wolski K, Aminian A, Brethauer $S$, et al. Bariatric surgery versus intensive medical therapy for diabetes - 5-year outcomes. N Engl J Med. 2017;376:641-51.

3. Buchwald $H$. The evolution of metabolic/bariatric surgery. Obes Sur. 2014;24:1126-35.

4. Diana M, Marescaux J. Robotic surgery. Br J Surg. 2015;102: e15-e28.

5. Himpens J, Leman G, Cadière GB. Telesurgical laparoscopic cholecystectomy. Surg Endosc. 1998;12:1091

6. Bindal V, Gonzalez-Heredia R, Masrur M, Elli E. Technique evolution, learning curve, and outcomes of 200 robot-assisted gastric bypass procedures: a 5-year experience. Obes Surg. 2015;25:997-1002.

7. Ramos A, Domene C, Volpe P, Pajecki D, D'Almeida L, Ramos $\mathrm{M}$, et al. Early outcomes of the first Brazilian experience in totally robotic bariatric surgery. Arq Bras Cir Dig. 2013;26(Supl. 1):2-7.

8. Smeenk R, van Hof G, Elsten E, Feskens P. The results of 100 robotic versus 100 laparoscopic gastric bypass procedures: a single high-volume centre experience. Obes Surg. 2016;26:1266-73.

9. Starnes C, Gochnour D, Hall B, Wilson E, Snyder B. The economy of motion of the totally robotic gastric bypass: technique, learning curve, and outcomes of a fellowship-trained, robotic bariatric surgeon. J Laparoendosc Adv Surg Tech. 2015;25:411-8.

10. Stefanidis D, Bailey S, Kuwada T, Simms C, Gersin K. Robotic gastric bypass may lead to fewer complications compared with laparoscopy. Surg Endosc. 2018;32:610-6.

11. Buchs N, Morel P, Azagury D, Jung M, Chassot G, Huber O, et al. Laparoscopic versus robotic Roux-En-Y gastric bypass: lessons and long-term follow-up learned from a large prospective monocentric study. Obes Surg. 2014;24:2031-9.

12. Hagen M, Pugin F, Chassot G, Huber O, Buchs N, Iranmanesh $P$, et al. Reducing cost of surgery by avoiding complications: the model of robotic Roux-En-Y gastric bypass. Obes Surg. 2012;22:52-61. 